\title{
Recognition and Interpretation: Responding to Emotional Experience in Psychotherapy
}

\section{Voutilainen, Liisa}

2010

Voutilainen , L , Peräkylä , A \& Ruusuvuori , J 2010 , ' Recognition and Interpretation:

Responding to Emotional Experience in Psychotherapy ' , Research on Language and

Social Interaction, vol. 43 , no. 1 , pp. 85-107 . https://doi.org/10.1080/08351810903474799

http://hdl.handle.net/10138/29486

https://doi.org/10.1080/08351810903474799

publishedVersion

Downloaded from Helda, University of Helsinki institutional repository.

This is an electronic reprint of the original article.

This reprint may differ from the original in pagination and typographic detail.

Please cite the original version. 
This article was downloaded by: [University of Helsinki]

On: 25 May 2011

Access details: Access Details: [subscription number 917206032]

Publisher Routledge

Informa Ltd Registered in England and Wales Registered Number: 1072954 Registered office: Mortimer House, 3741 Mortimer Street, London W1T 3JH, UK

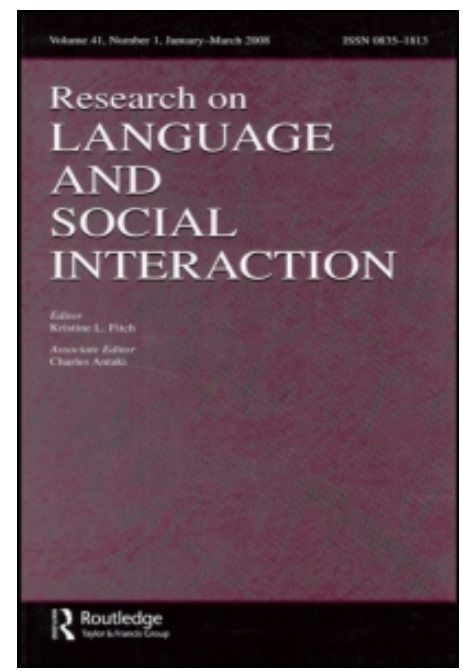

\section{Research on Language \& Social Interaction}

Publication details, including instructions for authors and subscription information:

http://www.informaworld.com/smpp/title $\sim$ content=t775653697

\section{Recognition and Interpretation: Responding to Emotional Experience in Psychotherapy}

Liisa Voutilainen; ; Anssi Peräkyläb; Johanna Ruusuvuoric

${ }^{\mathrm{a}}$ Department of Sociology, University of Helsinki, Finland ${ }^{\mathrm{b}}$ Helsinki Collegium for Advanced Studies, University of Helsinki, Finland ${ }^{c}$ Department of Social Research, University of Tampere, Finland

Online publication date: 12 February 2010

To cite this Article Voutilainen, Liisa, Peräkylä, Anssi and Ruusuvuori, Johanna(2010) 'Recognition and Interpretation: Responding to Emotional Experience in Psychotherapy', Research on Language \& Social Interaction, 43: 1, 85 - 107

To link to this Article: DOI: $10.1080 / 08351810903474799$

URL: http://dx.doi.org/10.1080/08351810903474799

\section{PLEASE SCROLL DOWN FOR ARTICLE}

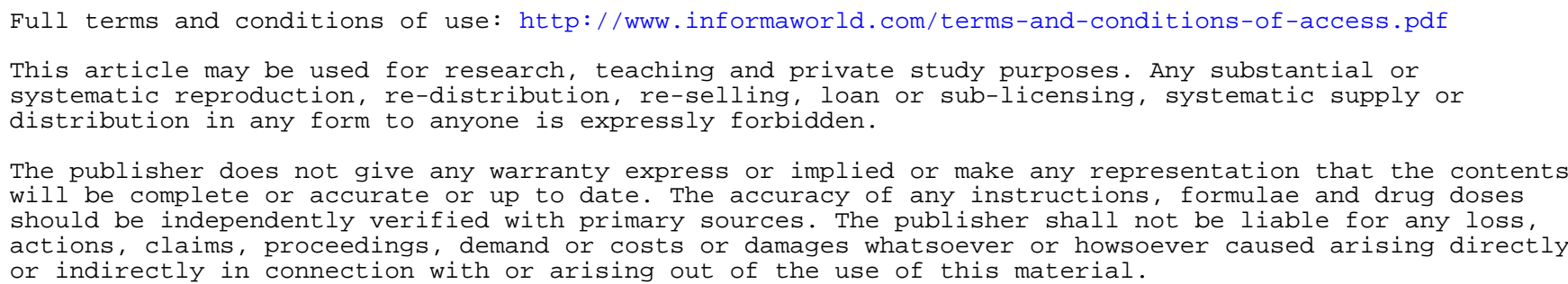




\title{
Recognition and Interpretation: Responding to Emotional Experience in Psychotherapy
}

\author{
Liisa Voutilainen \\ Department of Sociology \\ University of Helsinki, Finland \\ Anssi Peräkylä \\ Helsinki Collegium for Advanced Studies \\ University of Helsinki, Finland \\ Johanna Ruusuvuori \\ Department of Social Research \\ University of Tampere, Finland
}

\begin{abstract}
Based on conversation analysis (CA) of audio-recorded therapy sessions, the article explicates practices of responding to the patient's emotional experience in cognitive-constructivist psychotherapy. First, the article describes two types of therapist's actions after the patient's descriptions of an emotional experience: recognition and interpretation. In recognition, the therapist displays that she understands the patient's experience and sees it as real and valid. In interpretation, the therapist points at something that can be heard as implicit in what the patient expressed. Second, the article shows that these two actions are combined in specific ways in the therapist's turns at talk. It is suggested that recognition (emotional responsiveness) is a prerequisite of the therapist's more interpretive actions that imply access to the patient's experience. The empirical findings are discussed in relation to sociological studies on management of emotions in institutions and psychotherapeutic debates on cognitive and emotional aspects of therapeutic processes.
\end{abstract}

Emotional experience is a central object of attention in psychotherapy. Through interaction in the therapy sessions, the therapist and the patient are working with and possibly modifying the patient's problematic experiences. In the classical psychotherapeutic theories-including

Thank you to Paul Drew for commenting on an early version of this article, and Paul Drew, Riina Kasterpalu, Monika Vöge, and Dangjie Ji for the data sessions in York in Autumn 2006. Thanks also to Hanna Falk, Taru Ijäs, and Mikko Kahri for their comments on earlier versions of the manuscript, to Katri Takala and other transcribers of the data, and to participants of data sessions at University of Helsinki, Department of Sociology, during 2005-2006. This study was made possible by Academy of Finland project 1110845 (Emotion, Interaction, and Institutions).

Correspondence should be sent to Liisa Voutilainen, Department of Sociology, University of Helsinki, PO Box 4 (Vuorikatu 6), Helsinki, FI-00014, Finland. E-mail: liisa.voutilainen@helsinki.fi 
psychoanalysis and cognitive therapy - the therapeutic change is seen to take place through what can be called cognitive or intellectual processes in the patient's mind - in psychoanalysis through becoming conscious of unconscious phenomena (Greenson, 1967) and in cognitive therapy through modifying dysfunctional cognitions (Beck, 1976). More recently, however, it has been argued within both these traditions (e.g., Greenberg \& Safran, 1987; Stern, 2004), as well as elsewhere (e.g., Warner, 1997), that the processes through which the therapeutic change takes place might not have so much to do with gaining new insights or rationality but with new experiences of emotional expression and response in the therapeutic relationship-which are then supposed to transform the patient's ways of relating to others and his or her own experience. These ideas, which are now gaining a lot of support, have a rather long and diverse history (see Gendlin, 1964; Kohut, 1971; Rogers, 1959).

In this article our aim is to explicate, from the perspective of conversation analysis (CA), some specific ways in which the patient's emotional experiences are worked with in actual psychotherapy sessions. The data of the study consist of audio-recorded sessions of a therapist-patient pair from cognitive-constructivist therapy. This is a stream within cognitive therapy, which, besides examining the patient's cognitive schemes, emphasizes subjective meanings, emotions, aspects of developmental history, and issues of therapy relationship (see Guidano, 1991; Safran \& Segal, 1990; Toskala \& Hartikainen, 2005). Our aim is to approach actual practices in this particular therapy, not through psychotherapeutic concepts, but through means of conversation analysis, thus focusing on the relations between adjacent utterances (Schegloff, 2007). In the analysis of the data we use especially the applications of conversation analysis that are specialized in the study of institutional interaction (Arminen, 2005; Drew \& Heritage, 1992; Peräkylä, 2004a).

We will first describe two types of a therapist's initial responses to a patient's expressions of emotional experiences: one that recognizes the experience and one that interprets the experience. Thereafter, we will explicate the sequences that these different responses engender. Toward the end of the article, we will discuss our findings in relation to psychotherapeutic theories (see Peräkylä \& Vehviläinen, 2003), as well as compare management of emotion in psychotherapy to other institutional contexts.

\section{AFFECT AND EMOTION IN SOCIAL INTERACTION}

Emotion is anchored in physiological, psychological, cultural, and social processes. In our study, we investigate a particular aspect of this multifaceted phenomenon: the ways in which what is socially recognizable and interpreted as emotion is expressed, attended to, and responded to in real-time social interaction. A large number of earlier conversation analytical studies have touched upon emotional aspects of social interaction: See for example the studies on troubles-telling by Jefferson and Lee (Jefferson, 1980, 1988; Jefferson \& Lee, 1992), on accounting by Buttny (1993, Ch. 6), on delivery and reception of good and bad news by Maynard (1997, 2003; Freese \& Maynard, 1998), and on request sequences in parent-child interaction by Wootton (1997, Ch. 4). However, there have been few CA studies in which the organization of emotion and its expression has been the primary topic. Such studies include Goodwin and Goodwin (2000) on assessment sequences in everyday interactions, Hepburn (2004) on crying in helpline calls, Heath (1988) and Sandlund (2004, pp. 160-226) on embarrassment in medical consultations and academic seminars 
respectively, Ruusuvuori $(2005,2007)$ on managing expressions of troublesome experiences in medical and homeopathic consultations, Heath (1989) on expression of pain in medical consultations, and Whalen and Zimmerman (1998) on "hysteric" displays of anxiety in emergency calls. All these studies seek to describe the trajectories of interaction that lead to and engender from verbal or nonverbal displays of emotion, that is, displays that are oriented to (or interpreted as) emotional (see also Edwards, 1997, pp. 170-201).

The current study seeks to make a further contribution to this emergent line of CA research on emotion work. Arlie Hochschild (1979) talked about emotion management in referring to the work that an individual does to induce or inhibit feelings in order to render them appropriate to a situation. In the vein of Hochschild, we are in search of social rules that guide people in expressing emotion. However, our focus is not on the regulation of an individual's emotional expressions (the act of self-regulation that is practiced) in accordance with specific social rules, but on the ways in which emotion is managed in interaction, in and through concerted action between the participants in a specific situation. The institutional setting that we investigate makes such study particularly relevant, because a manifest institutional task of psychotherapy is to deal with and transform the patient's emotional experience.

\section{PSYCHOTHERAPY AS INTERACTION}

Psychotherapy has a long history as an object of linguistic and social scientific research. The starting point of the research tradition can be located in the work of Pittenger, Hockett, and Danehy (1961), which described in detail an audio recording of the first $5 \mathrm{~min}$ of an initial psychiatric interview, paying particular attention to the implicit meanings conveyed by the lexical and prosodic choices of the participants. Scheflen (1973) presented an equally impressive microanalysis of a segment of family therapy, focusing especially on the coordination of language, posture, and gesture of the participants. Labov and Fanshel (1977) analyzed a segment of psychotherapy interaction using speech act theory, and the line of their work was more recently continued by Ferrara (1994), who examined various discourse strategies (such as repetition of the other's talk, construction of metaphors, and joint production of utterances) in a large corpus of tape-recorded data.

In the 1990s, and especially after the turn of the century, conversation analytical research on psychotherapy rapidly increased. Conversation analysts have investigated actions such as questions and answers (MacMartin, 2008; Peräkylä, 1995), formulations (Antaki, 2008; Antaki, Barnes, \& Leudar, 2005; Buttny, 2004, chs. 2-3; Hutchby, 2005), and interpretations (Bercelli, Rossano, \& Viaro, 2008; Peräkylä, 2004c; Vehviläinen, 2003). In general, CA studies in this field investigate the ways in which the expressed understandings concerning the patient's experience get transformed in and through adjacent turns at talk (see Peräkylä, Antaki, Vehviläinen, \& Leudar, 2008). Even though affect and emotion are arguably central issues in psychotherapy, few CA studies have thus far explored the affective side of the therapeutic interaction (see, however, Peräkylä, 2008; Rae, 2008). One might say that the classical studies of Pittenger et al. (1961), Scheflen (1973), and Labov and Fanshel (1977) were more sensitive to emotional aspects of interaction. It is one of the tasks of this article to extend the repertoire of CA psychotherapy research toward emotional communication. 


\section{DATA AND FOCUS OF THE ANALYSIS}

The data corpus of this study consists of 57 audio recordings of cognitive-constructivist therapy sessions from one (Finnish-speaking) therapist-patient pair. This covers a time period of 18 months from a therapy process of 2 years. From the corpus 14 sessions have been transcribed as a whole and 12 sessions were partly transcribed. Parts to be transcribed have been selected on the basis of topics of talk in the sessions. The transcribed data from these 26 sessions covers approximately $20 \mathrm{hr}$ of recordings. As the study focuses on interaction of one therapist and one patient, we cannot claim that our findings are generalizable to all cognitive-constructive therapies, let alone other types of psychotherapy. Yet we do show in detail how cognitive-constructivist psychotherapy works (in relation to emotion) in this particular instance, and we also show how this particular psychotherapy is made possible by the participants making systematic use of the sequential organization of interaction (see Peräkylä, 2004b).

The object of our analysis is the therapist's initial responses to the segments of the patient's talk where the patient describes how she feels about somebody or something or what somebody or something is like. In many cases, these two analytically distinctive actions - describing an emotional experience and evaluating an object-intertwine in the patient's talk. In broad terms, these accounts can be heard as expressions of the patient's immediate experience: With them the patient describes the way she feels with regard to important people or events in her life, how she relates to them. For example, the patient might describe her feelings of not belonging in her childhood family or how she still cannot overtly resist her mother. It should be noted that we have excluded from our corpus cases where the patient is talking about what can be counted as feelings of depression or anxiety as such, without relating them to specific events or people. Such symptom descriptions are topically different objects than ones included here, and they seem to be treated differently by the therapist than the descriptions that are included. For example, an excluded case is where the patient describes her experience in terms of "that kind of anxiety, that kind of pressed feeling, or that kind of agonized feeling."

We will analyze particular kinds of utterances that follow the patient's expressions of an emotional experience. Firstly, the utterances in focus have the patient's inner experience as their referent, rather than referring to other issues such as the (external) situation that the patient might be worried about. Secondly, the utterances in focus are syntactically designed as responsive actions. In our data this means the utterances that are designed as statements, extensions to the patient's turn or formulations of the patient's preceding talk (see Vehviläinen, Peräkylä, Antaki, \& Leudar, 2008) —or most typically, the utterances that combine characteristics of these designs. We have excluded cases that operate through the organization of repair: for example, candidate understandings through which the therapist primarily checks whether she has understood correctly (some aspect of) the patient's account. Therefore, for example, a case where the therapist says "So you began to feel like that while you were there" is excluded from the analysis. The responses in focus are designed to indicate the availability of the patient's experience to the therapist. They are primarily not reformulating what was meant by the patient (cf. Antaki, 2008; Heritage \& Watson, 1979) or stating the therapist's own perspective (cf. Bercelli et al., 2008), but rather combinations of these actions. The therapist thus speaks from a shared perspective, indicating that the patient's experience is somewhat similarly available to both of the participants (cf. Peräkylä 2008; Vehviläinen, 2003). 
The definitions made previously are not clear-cut. We cannot say exactly at which point in continuums of different turn designs the patient's accounts on the state of affairs turn from nonaffective into affective (i.e., into what can be treated as expressions of an emotional experience), or at which point the therapist's evaluations of the patient's external circumstances turn into statements about the patient's experience, or at which point the therapist's candidate understandings of the patient's accounts turn into responses to such accounts. There are plenty of cases within these gray areas. Yet the cases included in this analysis fall somewhere toward the affective, experience-referring, and response ends of these continuums. The analysis reported here is based on a collection of 29 cases of this kind of patient accounts and therapist response.

\section{TWO TYPES OF THERAPIST'S RESPONSE}

The responses that have the patient's experience as their referent are basically of two kinds. One is what we call recognizing the patient's experience, and the other is what we call interpreting the experience. In recognizing, the therapist displays understanding of what the patient's experience is like (cf. Ruusuvuori, 2005). She both shows that she understands the informative aspect of the patient's emotional expression and simultaneously treats the patient's (emotional) experience as real and valid. By interpreting, in turn, we refer to interpretation in a generic psychotherapeutic sense, that is, pointing at something that is implicit in the patient's experience. In interpretation, the therapist offers the patient a new angle or connection to consider the experience in question, though heavily drawing upon the patient's preceding description of it.

As actions, recognition and interpretation are partially overlapping. Recognition can be done as mere recognition. It is this kind of response that we call recognition in this article. Interpretation, on the other hand, typically also has a component of recognition in it. So, recognition can be done without an interpretative component, while interpretation regularly also involves a recognition component.

Following, we will first give examples of these two different types of response, and then describe different trajectories of interaction that follow these responses. The first examples are of recognition.

\section{Recognizing the Emotional Experience}

Before Extract 1, the therapist has asked whether the patient feels that she could nowadays defend herself better than before in case her mother started to berate her. The patient has started her answer by figuring that maybe she would nowadays defend herself better. In the beginning of the extract she backs off and gives a more cautious estimation of her reaction in that hypotheticalal situation.

Extract 1

$1 \quad \mathrm{P:} \quad(0.7)$

2 .hh $>$ Maybe on the PH<ONE I MEAN if it .hh $>$ Ehkä PU $<$ HELIMES ET jos se

3 FACE TO FACE it is somehow so INSANELY strong KÄSVOKKAIN se on jotenki nii ÄLYTTÖMÄN voimakas

4 (.) or like that so that if it is face to face 
(.) tai sillä lailla että jos se on kasvokkain

5 .hh so then (.) then I guess I could li:ke(.)

so then then really like 0 could

.hh nii sitten (.) sit kyllä niinku: (.) saattas

$6 \quad$ \#seize up so that\#.

mennä \#lukkoo että\#.

$7 \quad(0.7)$

8 T: <Ts you wouldn't even be able to ${ }^{\circ}$ look at ${ }^{\circ}$ mother> (.)

$<$ Ts sä et vois ${ }^{\circ}$ katsookkaa ${ }^{\circ}$ äitiä> (.)

$\uparrow \mathbf{m m}[\mathbf{m m} . \uparrow$

mm [mm.

9 P: $\quad[$ Y- YEA:H.

$(0.9)$

In lines 2-6 the patient ponders that maybe she would be able to defend herself on the phone but probably not if she were facing her mother. She continues that when facing her mother "it is so strong" ("it" presumably referring to the feeling of panic) that then she might seize up. Thus, through describing the hypothetical situation, the patient is here describing her problematic emotional experience, that of (still) being afraid and unable to defend herself with her mother.

In line 8, the therapist rephrases what would happen in that hypothetical situation: The patient would not be able to even look at her mother. Earlier in the session, the patient has used this expression to describe her relationship with her mother. In line 8, the therapist uses the patient's own words as a resource to display that she has recognized what kind of experience the patient is referring to. ${ }^{1}$ The recognition is hearable as affective: The therapist uses an extreme-case formulation (Pomerantz, 1986): "wouldn't even be able to look" and produces her turn in a soft, comforting voice (on potential loci of affect in conversation, see Besnier, 1990; Ruusuvuori, 2005; Couper-Kühlen, 2006). In this response, the therapist does not add interpretive material to the description of the patient's experience. Instead, she concretizes the patient's figurative, idiomatic expression of seizing up, and thus preserves the patient's emotion as the focus of description and views it from a similar perspective.

In sequential terms, the therapist designs her turn as a syntactic extension of the patient's account (see Ferrara, 1994; Vehviläinen, 2003) rather than as a candidate understanding of it. ${ }^{2}$ The patient finishes her turn with "so that." Syntactically she could be starting a new unit of talk, but her creaky voice (see Ogden, 2001) and finishing intonation indicate a transition-relevance place. The therapist takes the turn but also the opportunity offered with the patient's trail-off (Ford \& Thompson, 1996, p. 139) to continue the patient's utterance from where she had finished. Further, the therapist does not preface her turn with markers such as so that or you mean to make a

\footnotetext{
${ }^{1}$ The silence of $0.7 \mathrm{~s}$ that follows the patient's turn of talk is typical for the general pace of conversation in these data: The therapist refrains from taking the turn immediately at the transition relevance place, allowing the patient to continue if she so chooses.

${ }^{2}$ It might be argued that the silence of $0.7 \mathrm{~s}$ that follows the patient's turn of talk is evidence against the interpretation that the therapist is extending the patient's turn rather than making a candidate understanding of it. However, such long silences are typical for the general pace of conversation in this type as well as other types of therapy data that we have worked with: The therapist usually refrains from taking the turn immediately at the transition-relevance place, allowing for the patient to continue if $\mathrm{s} / \mathrm{h}$ e so chooses.
} 
candidate understanding. Thereby, she adopts a footing (see Goffman, 1981) where she speaks from within the patient's experience, rather than reformulating what the patient has said about her experience. Further, the therapist uses a person reference, "you," when referring to the patient's feelings. This is intriguing, as in Finnish medical interaction, for instance, similar recognitions of the patient's experience are made using a so-called zero-person construction (Ruusuvuori, 2005, 2007). This construction, where the subject of the utterance is omitted and the verb is in thirdperson singular, is often used in Finnish when subjective experiences are offered as shareable, as potentially known by the other participants (Laitinen, 1995). In the extract, although the patient uses zero-person construction (see lines 5-6), the therapist chooses the "you" reference in her subsequent turn. The therapist thus claims knowledge of the patient's owned experience. In and through these means that display affect and epistemic access to the patient's experience, the therapist displays understanding of the patient's problematic experience as the patient offered it, and treats it as real and valid.

Extract 2 is another example of the therapist recognizing the patient's experience. Here the therapist and the patient have been talking about the patient's experience of being an outsider in her childhood family. The therapist has suggested that the patient may have felt left behind when her sister was born. Before the extract, the patient has elaborated on this interpretation by saying that she does remember always feeling that she was "falling between" her elder and younger siblings. The extract begins from where the patient summarizes her description of that experience.

Extract 2

$1 \quad$ P: I mean in a way et joteki

2 I experienced that I was like someone who (2.3) koin olevani semmonen niinku (2.3)

3 was in between (.) someone (1.4) who did siinä välissä (.)semmonen (1.4) millei

4 £not matter that much£ (1.1) [or like that= $5 \mathrm{~T}$ : £nhiin väliä£ (1.1) [tai jotain että=

$6 \mathrm{~T}:=$ Ts an outsider and.= [Mmm.

7 P: =Yeah.

$$
=\mathrm{Nii} \text {. }
$$

$8 \quad(2.3)$

9 T: $\mathrm{Mmmm}$.

10 (.)

11 T: $\mathrm{Mmmm}$

12 (2.1)

13 T: And there they were now again all of them Ja siellä ne nyt oli taas kaikki

14 together. koolla. (0.5)

$15 \mathrm{P}:=£$ NHII $£$ hhh nii. $=$ $=£ Y E A H £$ hhh yeah.= 
In lines 1-4 the patient describes her rather general childhood experience as "being in between" and "someone who did not matter that much." In line 6 the therapist displays (partial) understanding of the patient's experience ("outsider and"), which the patient confirms in line 7. In lines 9 and 11 the therapist produces $m m m$-tokens, which can be heard as acknowledging and closing the patient's description of her experience.

In lines 13-14 the therapist states "and there they were now again all of them together." The therapist is here referring to what the patient has told her earlier in the session about her grandfather's birthday celebration, which had been the previous day and which the patient did not attend. Thus, the therapist treats the patient's experience under discussion as one that does not only belong to the past but is currently present in her life (as the patient herself has indicated earlier in the session). With the "and"-preface at the beginning of her turn, the therapist builds her comment as an extension of the patient's turn. She describes the situation as if she were the one making the observation, though it is clear from the context that the question is about the patient's experience. The therapist's utterance also has complaining, idiomatic characteristics: expressive word order ("there they were"3) and extreme case formulation ("all") (on characteristics of complaining, see e.g., Günthner, 1997; Ruusuvuori \& Lindfors, 2009). Through these means, the therapist adopts (as she did in Extract 1) a position where she speaks from within the patient's problematic experience.

The therapist's responses in the previous examples were examples of what we call recognizing the patient's experience. These utterances preserved the patient's emotion in the focus of the description, and were hearable as affective. The therapist designed her responses as extensions of the patient's turn (rather than, for example, as formulations or candidate understandings of the patient's talk), thus adopting the patient's perspective toward her problematic experience. The therapist's utterances conveyed that the therapist understands what the patient has said, but also more: By giving details of the actual situation that the patient had been describing, by adopting the patient's affective stance, and by referring to the patient's experience in focus as something that she has access to, the therapist also treated the patient's experience as real and valid.

\section{Interpreting the Emotional Experience}

The next two examples show another type of initial response to the patient's affective talk, one which we call interpretation. In an interpretation, the therapist points out something that (in reference to therapeutic expertise) may be heard as implicit in what the patient has just been talking about (cf. Bercelli et al., 2008; Peräkylä, 2005; Vehviläinen, 2003). By pointing out this "something else" than what the patient said, the interpretations inherently also take some distance from the patient's own description of her experience. In the examples that follow, the therapist in a skillful way suggests an alternative interpretative framework to the one the patient has proposed and combines this with elements that recognize the patient's experience.

In Extract 3, the therapist and the patient are talking about the patient's wish to have a baby. Before the extract, the patient has stated that she wants to be a good mother and not to make the same mistakes her mother did. From line 3 in the extract, the patient turns to reflect that she may subconsciously treat her own child in the same ways her mother treated her.

\footnotetext{
${ }^{3}$ In Finnish, the word order is not fixed and can be used to emphasize specific items in a sentence (Vilkuna, 1989).
} 
Extract 3

1 P: s- sh- so I mean (0.4) looked at what she does (1.0) and how

s- se- siis sillai (0.4) kattonu mitä se tekee, $(1.0)$ ja miltä

2 I ha- I myself have felt.

se on ite- musta itestä tuntunu.

(1.5)

3 P: Or pro- (.) \#m\# prob $\uparrow$ ably (I rep-) (.) \#mm\#

Tai va- (.) \#m\# varm $\uparrow$ aanki tois- (.) \#mm\#

4 likely I do some of them (.) also to my own (.) he todennäkösesti osia niistä teen (.) myös oma (.) he

5 to my o(h)w (ha ha) $\mathrm{n}$.hh subco : nsciously but I mean o(h)ma(ha ha)lle .hh alita:jussa mut et

6 so : mehow that I know \#nn\# at least (.) I am aware of jo : tenki et tiedän \#nn\# ainaki (.) tiedostan että

7 what I (.) don't want to do and (.) what I mitä en (.) halua tehä ja (.) mitä

8 [do want to do. [haluan tehä.

9 T: [You would somehow want to. hhh be that goo : d [Sä haluisit jotenkin .hhh olla se hy:vä ä : iti mo:ther that lyou \#never\# had. mitä [sul \#ei\# koskaan ollu․

11 P:

12

13 P: Yea-ah.

[khm ((swallows))

$14(.)^{-}$

In lines $6-8$ the patient glosses her preceding talk (about wanting to be a good mother) by stating that at least she knows or is aware of what she does not want to do and what she wants to do. In relation to the patient's preceding talk, this expression, which explicitly distinguishes "the not wanting" from "the wanting," gets a meaning of expressing strong commitment to being a good mother and a different kind of mother than the patient's own mother has been. In this way the turn also conveys a critical stance toward the patient's mother.

In line 9-10 the therapist responds to the patient's elaboration by stating "you would somehow want to be that good mother that you never had." In this utterance, the therapist points out something that the patient has not explicitly mentioned about her wishes regarding her future motherhood, and thereby offers an interpretation. In her interpretation, the therapist takes a certain distance from, and slightly challenges, the patient's initial description of her experience. The therapist does take up this description in referring to the patient's wish to be a good mother, but this wish is redefined to wanting to be "that good mother that you never had." Through the attribute "that," the therapist proposes that the patient's current wish is directly connected to her past, unrealized wish. In other words, the therapist proposes that the patient is still wishing for "that" mother that she had wished for as a child. In this way the therapist slightly shifts the perspective from the patient's wishes regarding her future motherhood to her past disappointment with her own mother. It is also noticeable that the therapist starts her interpretative utterance at a point where the patient is moving on from a description of what she does not want to a description of 
what she does want: She formulates what the patient would want at the same time the patient is saying the "do want" part of her expression. In this way, too, the therapist's turn gets its challenging characteristic: The therapist is catching from the patient's own words that the patient's emotional experience conveys something else than what she offered.

While challenging the patient's description, this interpretation incorporates also a component of recognition of the patient's experience. The recognition is realized in a number of ways. First, the therapist produces the end part of the turn, where she refers to the patient's experience of never having a good mother (lines 9-10), in a soft, affective way. Second, as in Extracts 2 and 3, the therapist designs her turn as a statement about the patient's mind rather than as a candidate understanding of what the patient has said about her mind. Thereby, the therapist demonstrates that the patient's experience is somehow directly accessible to her. And third, the therapist's statement conveys, as its presupposition, an assessment of the mother as "not good." Through this presupposed assessment, the therapist claims recognition of a painful experience of the patient's (disappointment) that the patient did not explicitly bring forward in the preceding talk. In other words, the therapist displays recognition of the patient's experience, which experience is just being reformulated to contain something else than what the patient initially was offering. Thus, the therapist is doing a kind of paradoxical action where she incorporates elements of recognition to an interpretation, which in itself is an action that inherently challenges the patient's talk and takes it in another direction.

Extract 4 is another example of interpretation, involving similar dynamics of interpretation and recognition. The extract is from the same session as Extract 2 . The therapist and the patient have been talking about how the patient might have experienced the birth of her sister. Before the extract, the patient has made a shift from discussing that experience to stating how it is evident that her little sister really is her father's favorite child. The extract begins in the midst of the patient's turn.

\section{Extract 4}

$1 \quad$ P: She is really (1.3) spoiled and \#e : \# surely not se on oikeen (1.3) lellitty ja \#e : \# ei varmaan

2 like (1.9) or father surely will see her just as if niinku (1.9) tai isä pitää sitä varmasti ihan

3 she was (.) a little baby like (.) \#still\# .hhhhhh pikku (.) vauvana niinku (.) \#vielä\# .hhhhhh

$4 \quad$ after ten years £hheh .hhhhhhh£ (1.2) kymmenen vuoden päästäki £hheh .hhhhhhh£ (1.2)

5 mm-mm I mean (.) she is like (2.3) or not m-mmm että (.) kyllä se niinku (2.3) tai ei

6 spoiled but I mean in such a way it's not that $\downarrow$ lellitty mut siis sillä lailla ei se niinku

$7 \quad$ (2.0) but such .hhhhhhhhh (.) I mean an apple of (2.0) mut semmonen .hhhhhhhhhh (.) että isän

8 father's eye. silmäterä.

$9 \quad$ (.)

10 T: Mm-hm. 
11 T: Well quite a loss to you. Niin no aikamoinen menetys sulle.

$12 \quad($.

13 P: Mmm-m.

14 (.)

15 T: You would have wanted to be an apple of father's eye too Sääki oisit halunnu olla isän silmäterä.

$16 \quad($.

17 P: Yeah hhh. Nii hhh.

$18 \quad(0.4)$

19 T: Or an apple of somebody's eye (.) [mmmmm.

20 P: Tai jonku silmäterä (.) $\mathrm{m}[\mathrm{mmmm}$.

[Nii.

$21 \quad$ (3.9)

22 P: .hff And of course or STILL one would want to be .hff Ja totta $\uparrow$ kai $\uparrow$ tai $\uparrow$ VIELÄKIN $\downarrow$ haluais $\downarrow$ olla

In her turn (lines 1-8) the patient describes how her father gives special attention to her little sister. This turn is different from the patient's turns in previous examples, as here the patient is not describing her inner experience but (manifestly objectively) assessing the state of affairs in the outer world. This turn yet has an affective tenor; the patient takes a sneering stance to the treatment of her little sister and thus expresses indignation (through intensifiers "really" in line 1 and "surely" in line 2, exaggerations "little baby" in line 3 and "still after ten years" in line 4, and the figurative expression "apple of father's eye" in lines 7-8).

In line 11 the therapist responds by proposing that what the patient has just described is something that has been a "loss" to her. The therapist's response shifts the perspective from the outer world to the patient's inner experience. This way, the therapist's turn conveys, in a somewhat instant way, a psychotherapeutic interpretation: It suggests that in describing his father's relation to her sister, the patient is actually talking about her own painful experience. The therapist creates distance from the patient's initial description that focused on outer circumstances. At the same time, however, the therapist's response also incorporates recognition of the patient's experience that is being reformulated: The therapist states what the patient's experience has been like in an upgraded way (her choice of the word "loss" refers to the patient's experience as a rather severe one, and she further intensifies it with "quite"). As in the previous extract, also here the interpretation is designed as a direct statement, conveying some kind of an assessment. As the patient responds only minimally (lines 13 and later 17), the therapist expands her turn in lines 15 and 19. These expansions explicate or unpack the interpretive contents of the response. Again, in an even more interwoven way than in the previous instance, the therapist is here recognizing the patient's emotional experience while conveying an interpretation that slightly challenges what the patient has said.

The previous four examples presented two different experience-oriented ways in which the therapist can receive the patient's expressions of an emotional experience: recognition and interpretation. We will now turn to discuss what happens after the therapist's different responses. 


\section{ENGENDERED INTERPRETIVE TALK}

The therapist's responses to the patient's emotional experience engender different trajectories of interaction. However, the two types of response lead to a same kind of end result: a point where the patient's self-reflective talk about her mind is relevant. The therapist's interpretation makes such self-reflective talk relevant immediately, in the next turn by the patient. Recognition, in turn, first invites agreement from the patient, which agreement then can be followed by the therapist's more interpretative utterance. This interpretation, then, makes relevant the patient's self-reflective talk. So, both responses work toward making relevant self-reflective talk from the patient, but one response-recognition - takes a longer route, as it were.

We will first describe the actions that follow the responses where the therapist recognizes what the patient was offering. Extract 5 shows the therapist's response (recognition) from example 1, and how the interaction proceeds from it. The therapist and the patient are talking about the patient's reaction in a hypothetical situation where the patient's mother would be berating the patient.

Extract 5

1 P: (.) or like that so that if it is face to face

(.) tai sillä lailla että jos se on kasvokkain

2 .hh so then (.) then I guess I could li : $\mathrm{ke}($.)

.hh nii sitten (.) sit kyllä niinku: (.) saattas

3 \#seize up so that\#. mennä \#lukkoo että\#.

$4 \quad(0.7)$

5 T: $<$ Ts you wouldn't be able to ${ }^{\circ}$ even look at ${ }^{\circ}$ mother $>$ (.) $<$ Ts sä et vois ${ }^{\circ}$ katsookkaa ${ }^{\circ}$ äitiä> (.)

$6 \uparrow \mathbf{m m}[\mathbf{m m}$.

$\uparrow \mathbf{m m}[\mathbf{m m}$.

7 P: $\quad$ YY- YEA:H.

$(0.9)$ [N- NII:.

9 P: .hff So that she: (.) she like somehow (.) .hff Et se: (.) se niinkü jotenki (.)

$10 \downarrow$ just by $\downarrow$ looking at me $£ W O U L D$.hh floor me $\downarrow$ katseen $\downarrow$ voimalla $£$ SHAIS .hh sais mut

11 so $\uparrow$ thatf maan tasalle et $\uparrow$ tä: $£$.

$(0.5)$

12 T: (that's) Right (.) then she would be again tha:t mo:ther

$\downarrow$ Nii (.) sit se olis se taas se: ä:iti

13 that you as a child were af [ $[\uparrow$ raid of. jota sä oot pienenä pe[län $\uparrow$ ny.

14 P:

[Nii : (.) nii-i.

[Yea : h (.) yea-h.

$15 \quad$ (.)

16 T: Even $^{\circ}{ }^{\circ}$ more $^{\circ}$

Enemmän ${ }^{\circ} \uparrow$ vie [lä. ${ }^{\circ}$ 
P: $\quad[$ Yea $:: \mathrm{h}$.

[Nii :: .

$18 \quad($.

19 T: $\uparrow \mathrm{Mmm} .=$

20 P: =ON THE PHONE I think it @ could be@.hhhh \#<so : >\#.

$21(0.8)$

$=$ PUHELIMESSA SAATTASKI @olla että@.hhhh \#<että : >\#.

22 P: $\uparrow \mathrm{Mm}-\uparrow \# \mathrm{mmm}-\mathrm{mmm} \#$ I'd fight and then hang £then HANG

$\uparrow \mathrm{Mm}-\uparrow \#$ mmm-mmm\# taistella ja lyödä £sitte LHUURIN

$23 \uparrow$ UP $\uparrow$ ANDH .hhhh£ and (.) $\downarrow$ and $\downarrow$ like (0.9)

$\uparrow$ KHORVAAN $\uparrow J A H ~ . h h h h £$ ja (.) $\downarrow$ ja $\downarrow$ niinku (0.9)

24 I could ESCAPE the situation easily [then tsiit tilanteest sillai pääsis helposti POIS [sitte.=

25 T:

$[\mathrm{Mmm}$.

$26 \mathrm{~T}:=\mathrm{Mm}-\downarrow \mathrm{hm}$.

$27 \quad(0.6)$

28 P: But then $>I$ 'm like if it's face to face I am< Mutta sit >on jotenki jos kasvokkain siin on<

29 stuck in the situation \#I'm not able to escape and\# jumiss siin tilantees \#ettei pääse pakoon ja\#

30 (.) \#or like $\uparrow @$ that $\uparrow$ so:@ .hhh=

(.) \#tai tolla $\uparrow @ 1$ lailla $\uparrow$ että:@.hhh=

$31 \mathrm{~T}:=\mathrm{Mmm} .=$

32 P: $=$ So it is so.

$=$ Et sit on.

$33 \quad(2.3)$

34 T: @Pt. You have indeed been awfully scared of her@.= @ Ts kyl sä oot sitä hirveesti pelänny@.=

$35 \mathrm{P}:=£ \mathrm{Mm}-\mathrm{m}$ hmhh£.

$36 \quad$ (.)

$37 \mathrm{~T}:{ }^{\circ}<$.As a little. [.girl ${ }^{\circ}>$ ].

${ }^{\circ}<$.Pienenä. [.tyttönä ${ }^{\circ}>$ ].

38 P: $\quad[$ Yea $: \mathrm{h}$

[Nii : .

$39 \quad($.

40 T: @Been@ (.) humble little ${ }^{\circ}$ girl ${ }^{\circ}$ (.) tried to $\uparrow$ be

41 @ Ollu@ (.) nöyrä pieni ${ }^{\circ}$ tyttö ${ }^{\circ}$ (.) yrittäny $\uparrow$ olla.

After the therapist's recognizing utterance (in line 5-6), the patient emphatically confirms the rephrasing of her emotional reaction in the hypothetical situation (line 7). In lines 9-11 she goes on, describing her emotional reaction in the hypothetical situation, now in a more elaborated way than in her previous turn (lines 1-3). In this turn, the patient agrees with the therapist's rephrasing of the emotional experience under discussion (not being able to look at her mother).

In lines 12-13 the therapist responds to the patient's elaboration first by an agreement token $\mathrm{Nii}$ and then by a further elaboration of the situation. The content of this elaboration is now more interpretive: The therapist suggests that in the situation they are hypothesizing, the mother would 
be again "that" mother whom the patient "as a child" was afraid of. Again (as in Extract 3), the therapist uses the phrase "that mother" to link the patient's current experience to her past experience. Here the therapist seems to suggest that the fear that the patient talks about was associated with her mother in her childhood. The therapist's utterance would make it possible for the patient to take up, in self-reflection, the relation between her childhood mother and the current mother. In her subsequent turns (lines 14, 17, and 20-32), however, the patient moves back to partly hypothetical descriptions of her interactions with the mother, and thus does not take up the opportunity for self-reflection. The therapist, in turn, retains the interpretative frame (and relevance of self-reflective talk) by pursuing the patient's childhood experiences about her mother as topic, making statements about how the patient felt as a little girl (lines 34-40).

It is notable that the sort of an interpretive utterance that the therapist made in lines 12-13 would have been possible to make already at line 5 where she responded to the patient's initial description of the hypothetical situation. Instead, by first recognizing the patient's experience, the therapist invited the patient's agreement and further elaboration. We would like to suggest that this way the therapist may be seen to build a stronger shared ground for the interpretation (cf. Peräkylä, 2004c; Vehviläinen, 2003).

Extract 6 shows another example of how recognition builds grounds for a more interpretive therapist's turn. The example shows the same response shown in Extract 2.

Extract 6

1 I experienced that I was someone who (2.3) koin olevani semmonen niinku (2.3)

2 was in between (.) someone (1.4) who did siinä välissä (.)semmonen (1.4) millei

3 Enot matter that much $£$ (1.1) [or like that= £nhiin väliä£ (1.1) [tai jotain että $=$

4 T: [Mmm.

5 T: $=$ Ts outsider and. $=$ $=$ Ts ulkopuoline $\mathbf{j a} .=$

6 P: =Yeah. $=$ Nii.

$7 \quad(2.3)$

8 T: $\mathrm{Mmmm}$.

$9 \quad$ (.)

$10 \mathrm{~T}$ : $\mathrm{Mmmm}$.

$11 \quad(2.1)$

12 T: And there they were now again all of them Ja siellä ne nyt oli taas kaikki

13 together. koolla.

$14 \quad(0.5)$

15 P: $=£$ NHII $£$ hhh nii. $=$ $=£ Y E A H £$ hhh yeah. $=$

$16 \mathrm{~T}:=$ So that just like the situation that you $=$ Et ihanku se tilanne just minkä sä oot have experienced before so. kokenu niinku ennenki ni. 
18

(.)

19 P: Ts \#y\#-yeah.

Ts \#n\#-niin.

$20 \quad$ (26.4)

$21 \mathrm{~T}$ :.hfff@When you as a child@, liked father and he

.hfff@Ku sälapsena@tykkäsit siitä ja se

Here the patient described her rather general experience of being an outsider in her childhood family, and the therapist responded by referring to a specific situation in the patient's current life where this experience was again actualized (lines 12-13). This therapist's turn had a complaining character; she was speaking from within the patient's position where the rest of the family is treating the patient badly. The patient's response to this recognition is a very strong "yeah" (nii) followed by an outbreath and another "yeah" (nii). Nii as a response to a display of understanding by the therapist confirms the therapist's view on the patient's experience (Sorjonen, 2001; Ruusuvuori, 2005). Thus, there is a strong ground of mutual understanding reached at that point; and it is on that ground that the subsequent turn is anchored.

In line 16 the therapist continues with a psychotherapeutic interpretation in which she links the patient's current experience to something that the patient has experienced before. Through turninitial "so that," the interpretation is offered as an upshot of the therapist's initial response (where she recognized the patient's experience). In her interpretation, the therapist returns to what she has suggested earlier in the session (data not shown): that the patient's general experience of being an outsider in her family has its roots in the time when the patient's sister was born. By offering her interpretative response only after the recognizing one, the therapist built first a ground of mutual agreement on which she then anchored the more interpretive response.

Yet it seems that the patient is not totally buying the therapist's interpretation here. Her nii response at line 19 is hearable as cautious: In relation to her previous nii it is considerably less enthusiastic, and after that there is a long pause in line 20; the patient does not go further on elaborating the interpretation (cf. Bercelli et al., 2008; Peräkylä, 2005). After the pause, the therapist continues with a question that looks back to the times in the patient's childhood that were discussed earlier.

We will next turn to the responses where the therapist immediately responds to the patient's affective talk with interpretation. We will discuss the means through which the therapist in these turns makes relevant the patient's self-reflective talk and how the patient can orient to the selfreflective position. Extract 7 shows how the interaction that was first shown in Extract 2 evolved.

Extract 7

$1 \quad$ P: so:mehow that I know \#nn\# at least (.) I am aware of jo:tenki et tiedän \#nn\# ainaki (.) tiedostan että

2 what I (.) don't want and (.) what I mitä en (.) halua tehä ja (.) mitä

3 [do want to do. [haluan tehä.

4 T: [You would somehow want to. hhh be that goo : d [Sä haluisit jotenkin .hhh olla se hy : vä ä : iti

5 mo:ther that [you \#never\# had. mitä [sul \#ei\# koskaan ollu․ 


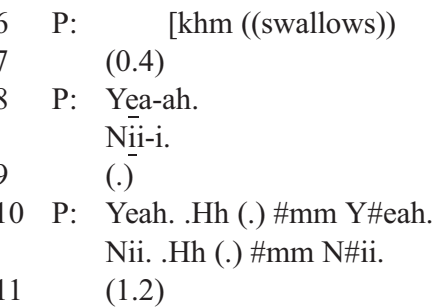

12 P: And now(h) hnow $\mathrm{h}>$ £now we get the $\mathrm{p}$ : icture that

13 that I want somehow like live then that $<. h \mathrm{~h}$ et mä haluun jotenki elää sit niinku sitä< .hh

14 (.) \#o u u \# with the ba- like have that life (.) \#o u u \# sen kau- sillei lapsen kautta tai

15 with the child somehow, $\# \bar{m} m \# \uparrow I \overline{\text { don}}$ 't know jōenki, \#mm\# $\uparrow$ Emmätiiä

$16>$ it can $\uparrow$ partly be that too but voihan >se $\uparrow$ osittain ehkä olla niinki mutta

17 I mean $<$.hhh (0.5) \#mm\# (0.5) Yeah. =And ye:s että< .hhh $(0.5)$ \#mm\# $(0.5)$ Nii. $=\overline{\mathrm{Ja}}$ ky:llä

18 I want to be a good mother tha:t haluan olla hyvä äiti m:itä

19 I did not $[(0.3)<$ have myself. $>$

$20 \mathrm{~T}: \quad\left[{ }^{\circ} \mathrm{Mm}^{\circ}\right.$ ei $\quad[(0.3)<$ ei itellä. $>$

$21 \quad(1.8)$

22 P: $>$ It is jus- $<$ HARrd to say $>$ I can't even now $>$ Se on va- $<$ PAha sanoo $>$ emmä voi vieläkään actually say that $<\# £$ mother was not a good mother£\#. oikeestaan sanoo että< $\# £$ äiti ei ollu hyvä äiti£\#. (.)

Here, in lines 4-5 the therapist made an interpretive turn that indicated that the patient's wish to be a good mother and different from her own mother is directly connected to her experience of "never having a good mother." This response slightly challenged the patient's initial description of her experience and thus called for self-reflection: to elaborate her experience from the new perspective that was introduced by the therapist. The component of recognition combined with interpretation might strengthen this relevance, as it displays that the experience (disappointment) that the patient did not explicitly offer is accessible to the therapist and thus something that the patient herself has implicitly expressed. In her response (lines 8-23) the patient orients to the selfreflective position invoked by the interpretation. In lines 8 and 10 she utters three times the confirming response particle "yeah" (nii). The pauses between the nii-responses and the mmsound preceding the last nii can be heard as displaying that she is processing what the therapist has said - thinking it over, examining it in her own mind. In lines 12-15 the patient explicates the challenging point possibly implied in the therapist's interpretation - that the patient's wish to have a baby might be a wish to gain compensation, through the baby, for her lack of good motheringand starts to reflect upon it. The orientation to self-reflection is incorporated in the patient's choice 
of words, as she prefaces this point with the words "now we get the picture" (line 12), instead of referring to this point as the therapist's suggestion. Thus, here the therapist's interpretation successfully invited interpretive, self-reflective talk from the patient, who started to elaborate her experience from a new perspective (cf. Bercelli et al., 2008; Peräkylä, 2005).

Extract 8 shows another example of an interpretive response and the patient's subsequent utterances. In the beginning of the extract, the patient is describing how she felt when she heard that her mother has praised her to her grandfather. Before the extract, the patient has described how good it felt to hear that her mother can also say good things about her, not only about her sister. In the beginning of the extract the patient starts to talk about another side of her experience: about how it bothered her that her mother does not give praise to her directly.

Extract 8

1 P: And mm- I thought it was (.) it is $(0.3)$ on the Ja mm- must se oli (.) se on (0.3) toisaalta

2 other hand I was annoyed about that why $\downarrow$ can't she come harmitti että miks ei se $\downarrow$ voi tulla

3 and say it to me: $\downarrow$ : I mean [\#that, mu: $\downarrow$ lle sitä sanomaan että [\#että,

4 T: $\quad[\mathrm{Mmm}$.

5 P: [It would be so lovely to hear, [Se olis niin ihana kuulla,

$6 \quad \mathrm{~T}: \quad[\downarrow$ You would need it [so-o much.

7 P: [Yeah.

[Nii.

$8 \quad$ P: But like even that that was now getting this Mut et kyllä toiki oli nyt tollai välikäden

9 second hand(h) knowled(h)ge like felt just insanely ka(h)utta ku(h)ultuna niinku tuntu ihan älyttömän

10 good. .hhh and then I mean you can believe that it hyvältä. .hhh ja ku sit sen voi uskoo et se on totta

11 is true as why Marja would (make up) something like ku miks Marja nyt semmosta että

$12[$ @ $\uparrow$ oh yeah@ their mother said that=so that $(\mathrm{h})$ it has [@†nii joo@ että niitten äiti puhu että=et(h) se on

$13 \mathrm{~T}:\left[{ }^{\circ} \mathrm{Mm}\right.$,

In lines 2-3 the patient's utterance "why can't she come and say it to me" has a complaining, affective character, and it expresses disappointment. In line 5 the patient continues by describing another emotional experience, a wish to hear her mother praising her. This expression of a strong wish works here as an account for the frustration or disappointment that was expressed: The patient feels bad because she doesn't have something that she would love to have.

In line 6, simultaneously with the patient's account, the therapist states "You would need it so much." Thus, the patient and the therapist are doing the same kind of action at the same time: commenting on the frustrated or disappointed feeling of the patient. Both also use the intensifier "so," which intensifies the assessive content of their turns. However, unlike the patient, the therapist does not focus on the wished situation of hearing the praise but makes a statement 
about the patient's "need" to hear the praise. Thus, the therapist is here again doing interpretation: She creates distance from what the patient expressed and brings the focus to what can be heard to refer to the mental processes of the patient. The therapist's interpretative utterance is somewhat similar to the interpretive utterance that was shown in Extract 4, where the patient's turn had an overtly complaining character and the therapist responded by focusing on the patient's mind.

Both here and in Extract 4 the therapist's interpretative utterances also convey recognition of the patient's affect. Here in Extract 8, this work is also done, alongside the lexical choice, prosodically, with a low pitch in the beginning of the turn and a prolonged intensifier "so." Further, the therapist's turn is built as an extension of the patient's preceding turn, thus speaking from within the patient's experience. Thus, also here the combination of interpretation and recognition seems to make it relevant for the patient to elaborate her experience from the new perspective suggested by the therapist.

In line 7 the patient confirms the therapist's interpretation, and after it in lines 8-13 she continues to elaborate her experience. Unlike in the previous extract, here the patient does not continue in the interpretive frame invoked by the therapist; she does not continue reflecting her need to hear the praise from her mother. Instead, she returns to reporting the positive side of her experience when she heard about what her mother has said.

In summary, recognition and interpretation, as two different therapeutic responses to the patient's descriptions of an emotional experience, seem to lead the talk in the same direction. Through recognition, the therapist prepares a ground of affiliation, and a subsequent interpretative utterance can then be anchored on this ground. Thus, recognition takes a longer route to where interpretation, as initial response, gets immediately. The therapist's interpretation (either following recognition or responding directly to the patient's affective account) then creates an opportunity for the patient's self-reflective talk. However, more often than not, the patient declines this opportunity and directs the talk elsewhere than self-reflection. (In cases shown in this article, the patient actually took up the opportunity for self-reflection only in Extract 7). In the data of this study, after the therapist's interpretations, the patient takes up the self-reflective position in approximately one third of the cases.

\section{CONCLUSIONS}

In this article we have described the ways in which a cognitive therapist responds to her patient's expressions of an emotional experience. At the beginning of the article, we made a distinction between responses that focus on the patient's inner experience, and those that focus on other issues such as the external situation that the patient is concerned about. Even though psychotherapeutic sessions obviously involve both types of response, we consider the responses that focus on inner experience as ones through which the work of psychotherapy is done in specific intensity: They address directly the patient's relation to her experience, the modification of which is arguably the central task of psychotherapy (Peräkylä et al., 2008). Thus, responses that focus on the patient's inner experience can be considered as a particular sequential locus of psychotherapeutic work.

Among the responses that focus on the patient's inner experience, we found two basic types: recognition and interpretation. Recognition involves the therapist understanding the patient's experience, seeing it as valid, and agreeing with it. Interpretation suggests that there is something else involved in the patient's experience than what the patient herself overtly brings forward, but it also works to recognize the patient's experience. 
Ruusuvuori $(2005,2007)$ has recently reported analyses of medical doctors' and homeopaths' responses to patients' troubles-telling, and it is of interest to compare her results with the ones presented here. In general practice and homeopathy the professionals' responses to patients' troubles-tellings are often nonaffiliative. In most cases, instead of attending to the affect displayed by the patient, the professionals maintain the solution of the patient's (physical) problem as their sole orientation. Such nonaffiliative responses are seldom found in the psychotherapeutic data. However, in what Ruusuvuori calls "empathetic responses," the physicians and the homeopaths do something that comes close to what we have called recognition of the patient's experience: They describe the possible consequences of the patient's trouble, thereby showing that they consider the patient's worry as being valid and justified. Thus, it appears that in recognition/empathetic response, there is a common ground between psychotherapy and medical/homeopathic consultation: These responses can be found in both types of encounters.

There are two important differences, however. First, what we have called interpretation appears to be a response that is exclusively associated with psychotherapy. No comparable response type in medicine/homeopathy was found in Ruusuvuori's study. Interpretative response to affective account could then be considered as a particular fingerprint of psychotherapy as institutional interaction. This is all the more important if we bear in mind that in our data, responses that we called recognition also eventually steered the interaction toward interpretation.

Second, in Finnish-language data, there is a significant difference in the way in which the patients' trouble or emotional experience is recognized and appreciated in these two types of context. While in psychotherapy the therapist refers to the patient's experience with you, the second-person singular, in general practice and homeopathy the professionals regularly refer to it with a so-called zero-person construction. To give an example of the latter, when the patient discloses problematic information about her debt-load, for instance, the professional may answer "It is a burden, 0 (the missing person reference) frequently has to think about it as 0 remembers how much 0 owes to whom." Choosing a zero-person in referring to another participant's experience is a way to talk about someone in general, someone who, as a member of the same community, has knowledge of the sort of experiences that are talked about. Thus, it does not suggest a direct access to another person's experiences. Instead, it gives the participants an equal position where both can evaluate a somewhat generally understandable and accessible experience: Both the patient and the professional can (imaginatively) fill the gap of the missing subject with "I," with themselves. This is somewhat similar to what is achieved in English by use of one or a person (see Silverman, 1997, pp. 154-156). When the therapist uses "you"-reference while explicitly describing and concretizing the patient's inner experiences, she claims to have access to the patient's owned experience, to know how she feels (cf. Peräkylä \& Silverman, 1991). On the other hand, with the second-person singular "you," she explicitly singles out the experience that is talked about as belonging to the patient. This way she takes a specific role with regard to the topic, that is, the patient's emotional experience, as someone who has the right to know about the patient's experience, to suggest what goes on in the patient's emotional life, but yet avoids positing her self, her own emotions under evaluation. Thus, we could suggest that in and through their particular ways to do recognition the professionals in these different contexts also construct particular institutional roles and orientations to their institutional task. In general practice and homeopathy the professionals' empathetic responses usually precede the closure of the troublestelling sequence and serve to return to the problem-solving activity. Thus, the recognition and justification of the patient's problematic emotional state is treated as a side issue, as not a part of the 
actual agenda of the encounter. (See Ruusuvuori, 2007.) In the (cognitive-constructivist) psychotherapy that we have analyzed, on the other hand, the particular way in which the psychotherapist recognizes the patient's emotional experience, and the way that this recognition is designed to enhance the patient's self-reflection, specifically point at the particular institutional task of working with the patient's problematic experiences.

In this article, recognition and interpretation have been considered as distinct conversational acts that are conveyed by specific utterances. This approach arises from our method and theory of investigation, conversation analysis. However, recognition and interpretation can also be seen more broadly, as two central functions of psychotherapy. It is a central task - maybe the central task - of a psychotherapist to convey to the patient that her experiences are real and valid (recognition) and to show her that these experiences have a comprehensible history and linkages to other experiences (interpretation). Our analysis has shown how these tasks are realized in and through turns at talk: their placement, design, and relations.

At the beginning of this article, we referred to a basic tension within psychotherapeutic theories. Some theories emphasize the change in dysfunctional cognitions as the source of the therapeutic change, while others see new experiences of emotional expression and interaction as the key to the change. As a conversation analytical study, ours cannot take a stance between rival professional theories. However, our results can be reflected upon in the context of this psychotherapeutic discussion (see Peräkylä \& Vehviläinen, 2003).

In this study, we have shown both cognition/consciousness-centered and emotion-centered therapeutic actions: What we called interpretation involves the former and what we called recognition involves the latter. Our main message to the therapeutic debate is, however, that in our data, the interpretive response to the patient's expression of an emotional experience always goes hand in hand with the recognition of that experience. We have shown two ways in which these two actions are intertwined. In one, the recognition of the experience as the patient told it precedes interpretation as a separate act, and in the other, recognition is done through the very interpretation (and then, what is affectively recognized is the experience that the therapist suggests is somehow beyond the experience that the patient described). So, we could suggest that in the therapist's response to the patient's expression of an emotional experience, there is no interpretation without recognition. This means that the emotional responsiveness-empathetic response (cf. Ruusuvuori, 2005) - is a prerequisite of the more cognitive, interpretative actions.

Our understanding comes close to what Greenberg and Elliot (1997) suggested in their integrative theory on experiential psychotherapy. They argue that therapists' empathetic responses also convey, in varying degrees, interpretive content. We have been exploring similar phenomena from another direction, showing that interpretations referring to the patient's affective accounts go together with varying forms of empathetic recognition of the patient's experience. Therefore, we would like to hypothesize that the two poles in the general psychotherapeutic debate - the cognition-centered and the emotion-centered - might not represent two distinguishable psychotherapeutic ways of working, but rather, they would involve theoretical idealizations that foreground one or the other basic psychotherapeutic actions which, in practice, need both be there.

It should be borne in mind, however, that our data come from one therapist-patient dyad, operating within the context of one particular psychotherapeutic approach. Therefore, clarifying the ways in which recognition and interpretation are organized in other types of psychotherapy remains the task for future studies. We hope that our analysis can offer some parameters for future comparative studies. 


\section{REFERENCES}

Antaki, C. (2008). Formulations in psychotherapy. In A. Peräkylä, C. Antaki, S. Vehviläinen, \& I. Leudar (Eds.), Conversation analysis and psychotherapy (pp. 26-42). Cambridge, England: Cambridge University Press.

Antaki, C., Barnes, R. \& Leudar, I. (2005). Diagnostic formulations in psychotherapy. Discourse Studies, 7, $627-647$.

Arminen, I. (2005). Institutional interaction. Aldershot, England: Ashgate.

Beck A. T. (1976). Cognitive therapy and the emotional disorders. New York, NY: International Universities Press.

Bercelli, F., Rossano F., \& Viaro, M. (2008). Clients' responses to therapists' re-interpretations. In A. Peräkylä, C. Antaki, S. Vehviläinen, \& I. Leudar (Eds.), Conversation analysis and psychotherapy (pp. 43-62). Cambridge, England: Cambridge University Press.

Besnier, N. (1990). Language and affect. Annual Review of Anthropology, 19, 419-451.

Buttny, R. (1993). Social accountability in communication. London, England: Sage.

Buttny, R. (2004). Talking problems: Studies on discursive construction. Albany, NY: State University of New York Press.

Couper-Kühlen, E. (2006, May). A sequential approach to affect: The case of "disappointment." Plenary presentation at the International Conference on Conversation Analysis (ICCA 06), Helsinki, Finland.

Drew, P., \& Heritage, J. (1992). Analyzing talk at work: An introduction. In P. Drew \& J. Heritage (Eds.), Talk at work: Interaction in institutional settings (pp. 3-65). Cambridge, England: Cambridge University Press.

Edwards, D. (1997). Discourse and cognition. London, England: Sage.

Ferrara, K. W. (1994). Therapeutic ways with words. Oxford, England: Oxford University Press.

Ford, C., \& Thompson, S. (1996). Interactional units in conversation: Syntactic, intonational, and pragmatic resources for the management of turns. In E. Ochs, E. A. Schegloff, \& S. Thompson (Eds.), Interaction and grammar (pp. 134-185). Cambridge, England: Cambridge University Press.

Freese, J., \& Maynard, D. (1998). Prosodic features of bad news and good news in conversation. Language in Society, 27, $195-219$

Gendlin, E. T. (1964). A theory of personality change. In P. Worchel \& D. Byrne (Eds.), Personality change (pp. 100-148). New York, NY: Wiley.

Goffman, E. (1981). Footing. In Forms of talk (pp. 124-127). Philadelphia, PA: University of Pennsylvania Press.

Goodwin, M. H., \& Goodwin, C. (2000). Emotion within situated activity. In N. Budwig, I. C. Uzgiris, \& J. V. Wertsch (Eds.), Communication: An arena of development (pp. 33-54). Mahwah, NJ: Lawrence Erlbaum.

Greenberg, L., \& Elliot, R. (1997). Varieties of empathic responding. In A. C. Bohart, \& L. Greenberg (Eds.), Empathy reconsidered: New directions in theory research \& practice (pp. 167-187). Washington, DC: APA Press.

Greenberg, L., \& Safran, J. (1987). Emotion in psychotherapy: Affect, cognition and the process of change. New York, NY: Guilford Press.

Greenson, R. (1967). The technique and practice of psychoanalysis. New York, NY: International Universities Press.

Guidano, V. (1991). The self in process. New York, NY: Guilford Press.

Günthner, S. (1997). Complaint stories: Constructing emotional reciprocity among women. In H. Kotthoff, \& R. Wodak (Eds.), Communicating gender in context (pp. 179-218). Amsterdam, The Netherlands: John Benjamins.

Heath, C. (1988). Embarrassment and interactional organization. In P. Drew \& A. Wootton (Eds.), Erving Goffman: Exploring the interaction order (pp. 136-60). Cambridge, England: Polity Press.

Heath, C. (1989). Pain talk: The expression of suffering in the medical consultation. Social Psychology Quarterly, 52, 113-125.

Hepburn, A. (2004). Crying: Notes on description, transcription and interaction. Research on Language and Social Interaction, 37, 251-290.

Heritage, J., \& Watson, R. (1979). Formulations as conversational objects. In G. Psathas (Ed.), Everyday language (pp. 123-162) New York, NY: Irvington Press.

Hochschild, A. (1979). Emotion work, feeling rules and social structure. American Journal of Sociology, 85, 551-575.

Hutchby, I. (2005). "Active listening": Formulations and the elicitation of feelings-talk in child counselling. Research on Language and Social Interaction, 38, 303-329.

Jefferson, G. (1980). On “trouble-premonitory” response to inquiry. Sociological Inquiry, 50, 153-185.

Jefferson, G. (1988). On the sequential organization of troubles talk in ordinary conversation. Social Problems, 35, 418-442.

Jefferson, G., \&. Lee, J. R. (1992). The rejection of advice: Managing the problematic convergence of a "troubles telling" and a "service encounter." In P. Drew \& J. Heritage (Eds.), Talk at work (pp. 521-571). Cambridge, England: Cambridge University Press.

Kohut, H. (1971). The analysis of the self. New York, NY: International Universities Press. 
Labov, W., \& Fanshel, D. (1977). Therapeutic discourse: Psychotherapy as conversation. New York, NY: Academic Press. Laitinen, L. (1995). Nollapersoona [Zero-person construction]. Virittäjä, 3, 337-358.

MacMartin, C. (2008). Resisting optimistic questions in narrative and solution-focused therapies. In A. Peräkylä, C. Antaki, S. Vehviläinen, \& I. Leudar (Eds.), Conversation analysis and psychotherapy (pp. 80-99). Cambridge, England: Cambridge University Press.

Maynard, D. (1997). The news delivery sequence: Bad news and good news in conversational interaction. Research on Language and Social Interaction, 30, 93-130.

Maynard, D. (2003). Bad news, good news: Conversational order in everyday talk and clinical settings. Chicago, IL: University of Chicago Press.

Ogden, R. (2001). Turn transition, creak and glottal stop in Finnish talk-in-interaction. Journal of the International Phonetics Association, 31, 139-152.

Peräkylä, A. (1995). AIDS counselling: Institutional interaction clinical practice. Cambridge, England: Cambridge University Press.

Peräkylä, A. (2004a). Conversation analysis. In C. Seale, D. Silverman, J. Gubrium, \& G. Gobo (Eds.), Qualitative research practice (pp. 165-179). London, England: Sage.

Peräkylä, A. (2004b). Reliability and validity in research based on naturally occurring social interaction. In D. Silverman (Ed.), Qualitative research: Theory, method and practice (pp. 283-304). London, England: Sage.

Peräkylä, A. (2004c). Making links in psychoanalytic interpretations: A conversation analytic view. Psychotherapy Research, 14, 289-307.

Peräkylä, A. (2005). Patients' responses to interpretations: A dialogue between conversation analysis and psychoanalytic theory. Communication \& Medicine, 2, 163-176.

Peräkylä, A. (2008). Conversation analysis and psychoanalysis: Interpretation, affect and intersubjectivity. In A. Peräkylä, C. Antaki, S. Vehviläinen, \& I. Leudar (Eds.), Conversation analysis and psychotherapy (pp. 100-119). Cambridge, England: Cambridge University Press.

Peräkylä, A., Antaki, C., Vehviläinen, S., \& Leudar, I. (2008). Analysing psychotherapy in practice. In A. Peräkylä, C. Antaki, S. Vehviläinen, \& I. Leudar (Eds.), Conversation analysis and psychotherapy (pp. 5-25). Cambridge, England: Cambridge University Press.

Peräkylä, A., \& Silverman, D. (1991). Owning experience: Describing the experience of other persons. Text, 11, 441-480.

Peräkylä, A., \& Vehviläinen, S. (2003). Conversation analysis and the professional stocks of interactional knowledge. Discourse and Society, 14, 727-750.

Pittenger, R. E., Hockett, C. F., \& Danehy, J. J. (1961). The first five minutes: A sample of microscopic interview analysis. Ithaca, NY: Paul Martineau.

Pomeranz, A. (1986). Extreme case formulations: A way of legitimizing claims. Human Studies, 9, 219-229.

Rae, J. (2008). Lexical substitution as a therapeutic resource. In A. Peräkylä, C. Antaki, S. Vehviläinen, \& I. Leudar (Eds.), Conversation analysis and psychotherapy (pp. 62-79). Cambridge, England: Cambridge University Press.

Rogers, C. R. (1959). A theory of therapy, personality and interpersonal relationships, as developed in the client-centered framework. In S. Koch (Ed.), Psychology: A study of science (pp. 184-256). New York, NY: McGraw Hill.

Ruusuvuori, J. (2005). "Empathy" and "sympathy" in action: Attending to patients' troubles in Finnish homeopathic and general practice consultations. Social Psychology Quarterly, 68, 204-222.

Ruusuvuori, J. (2007). Managing affect: Integrating empathy and problem solving in two types of health care consultation. Discourse Studies, 9, 597-622.

Ruusuvuori, J., \& Lindfors, P. (2009). Complaining about previous treatment in health care settings. Journal of Pragmatics, $41,2415-2434$.

Safran, J. D., \& Segal, Z. V. (1990). Interpersonal process in cognitive therapy. New York, NY: Basic Books.

Sandlund, E. (2004). Feeling by doing: The social organization of everyday emotions in academic talk-in-interaction. Karlstad, Sweden: Karlstad University Studies 36.

Scheflen, A. (1973). Communicational structure: Analysis of a psychotherapy transaction. Bloomington, IN: Indiana University Press.

Schegloff, E. A. (2007). Sequence organization in interaction: A primer in conversation analysis. Cambridge, England: Cambridge University Press.

Silverman, D. (1997). HIV counselling as social interaction. London, England: Sage.

Sorjonen, M-L. (2001). Responding in conversation. A study of response particles in Finnish. Amsterdam, The Netherlands: Benjamins. 
Stern, D. (2004). The present moment in psychotherapy and everyday life. New York, NY: W.W. Norton \& Co.

Toskala, A., \& Hartikainen, K. (2005). Minuuden rakentuminen. Psyykkinen kehitys ja kognitiivis-konstruktiivinen psykoterapia [Construction of Self. Psychic development and cognitive-constructivisit psychotherapy]. Jyväskylä, Finland: Jyväskylän koulutuskeskus.

Vehviläinen, S. (2003). Preparing and delivering interpretations in psychoanalytic interaction. Text, 23, 573-606.

Vehviläinen, S., Peräkylä, A., Antaki, C., \& Leudar, I. (2008). A review of the conversational practises of psychotherapy. In A. Peräkylä, C. Antaki, S. Vehviläinen, \& I. Leudar (Eds.), Conversation analysis and psychotherapy (pp. 188-197). Cambridge, England: Cambridge University Press.

Vilkuna, M. (1989). Free word order in Finnish: Its syntax and discourse functions. Helsinki, Finland: Suomalaisen Kirjallisuuden Seura.

Warner, M. A. (1997). Does empathy cure? A theoretical consideration of empathy, processing, and personal narrative. In A. C. Bohart \& L. Greenberg (Eds.), Empathy reconsidered: New directions in theory research \& practice (pp. 125-141). Washington, DC: APA Press.

Whalen, J., \& Zimmerman, D. H. (1998). Observations on the display and management of emotion in naturally occurring activities: The case of hysteria in calls to 9-1-1. Social Psychology Quarterly, 61, 141-159.

Wootton, A. J. (1997). Interaction and the development of mind. Cambridge, England: Cambridge University Press. 